Jurnal Kebidanan Mutiara Mahakam, Vol 8, No 1, 2020, Hal 1-7

ISSN : 2623-2553 (Online)

ISSN : 2549-0532 (Cetak)

\title{
GAMBARAN KPD, WARNA KETUBAN DAN INFEKSI IBU DENGAN KEJADIAN INFEKSI BAYI BARU LAHIR DI RSUD ABDUL WAHAB SJAHRANIE
}

\author{
Amalia Rizkiannur Putri ${ }^{1}$, Sukartini ${ }^{2}$, Evi Fitriany $^{3}$ \\ ${ }^{1}$ Program Studi Kedokteran, Universitas Mulawarman, Samarinda \\ ${ }^{2}$ Laboratorium Ilmu Kesehatan Anak, Universitas Mulawarman, Samarinda \\ ${ }^{3}$ Laboratorium Ilmu Kesehatan Masyarakat, Universitas Mulawarman, Samarinda \\ Email : amaliarizkiannur@gmail.com,dr.sukartini@yahoo.com,evi.fitriany@gmail.com \\ Dikirim \\ Diterima \\ : 25 September 2019 \\ Diterbitkan \\ : 28 Januari 2020 \\ : 20 Maret 2020
}

ABSTRACT

The early 28 days of life called the neonatal period is the most vulnerable period for infants. The infants face the highest risk of death in the first month after birth. The most common cause of infant death is asphyxia, prematurity, and infection. Infection in newborns is defined as a condition where the newborns have a disease caused by microorganisms. One of the risk factors causing infection in newborns includes factors from the mother, such as premature rupture of membranes, green or meconium and smelly amniotic fluid, maternal infection, and others. The main objective of this research was to describe the risk factors of incidence of infection in newborns at RSUD Abdul Wahab Sjahranie Samarinda. This research uses a retrospective descriptive method with the cross-sectional approach. Sampling was done by taking data on medical records of patients at the RSUD Abdul Wahab Sjahranie Medical Record Installation using total sampling technique. The results obtained were 99 samples that met the inclusion and exclusion criteria with details of patients who experienced premature rupture of membranes by 18 people (18,2\%), poor amniotic color by 62 people (62,6\%), mothers who had leukocytosis by 15 people (15,2\%), and the incidence of infection in newborns by 2 people (2\%). the collected data were tabulated bu frequency and percentage and displayed in tables.

Keywords: premature rupture of membranes, amniotic color, maternal infection, maternal leukocytosis, newborn infection 
Jurnal Kebidanan Mutiara Mahakam, Vol 8, No 1, 2020, Hal 1-7

\section{PENDAHULUAN}

Bayi baru lahir adalah bayi umur 0 sampai dengan 28 hari(Permenkes RI, 2014). Pada 28 hari kehidupan yang disebut dengan periode neonatal adalah masa paling rentan pada bayi (Kementrian Kesehatan Republik Indonesia, 2018). Bayi menghadapi risiko kematian tertinggi pada bulan pertama setelah lahir dengan rata-rata global sebesar 18 kematian per 1.000 kelahiran pada tahun 2017. Secara global, 2,5 juta anak mengalami kematian pada usia satu bulan. Sekitar 7.000 kasus kematian neonatal setiap harinya. Diantaranya terjadi pada minggu pertama dengan jumlah 1 juta kematian pada hari pertama dan mendekati 1 juta kematian pada 6 hari kemudian (United Nations Children's Fund, 2018). World Health Organization (WHO) tahun 2015 mengungkapkan bahwa rata-rata kematian bayi hampir 5 juta per tahun dengan 98\% kematian terjadi pada negara berkembang. Berdasarkan statistik ini, penyebab kematian bayi yang paling sering terjadi adalah karena asfiksia, prematuritas, dan infeksi. Sebuah analisis sistematikpada dunia, regional dan nasional menunjukkan bahwa 2 penyebab kematian pada anak di India tahun 2013 adalah komplikasi kelahiran preterm yang teridentifikasi dan infeksi (Sankar, et al., 2016).

Infeksi pada bayi baru lahir didefinisikan sebagai suatu kondisi dimana bayi baru lahir mengalami penyakit yang disebabkan oleh mikroorganisme, baik bakteri, virus, ataupun jamur (National Institute for Health and Care Excellence, 2014). Infeksi neonatal mencakup berbagai infeksi sistemik pada bayi baru lahir, seperti septikemia, meningitis, radang paru-paru, radang sendi, osteomyeitis, dan lain-lain (Stefanofic I., 2011). Faktor risiko yang menyebabkan infeksi neonatal terdiri dari faktor ibu, faktor bayi dan faktor lainnya (Boskabadi, et al., 2016).

Beberapa faktor risiko yang berasal dari ibu terdiri dari KPD dan ketuban pecah lebih dari 18 jam sebelum melahirkan, cairan ketuban hijau keruh atau mekonium dan berbau, dan infeksi pada ibu (Boskabadi, et al., 2016). Kejadian infeksi neonatal setelah ketuban pecah yang bertahan selama 24 jam adalah $1 \%$, dan setelah inspeksi klinis, insiden meningkat hingga 3-5\%. Secara umum, infeksi neonatal meningkat sepuluh kali lipat pada kasus KPD tanpa komplikasi (Ocviyanti \& Wahono, 2018). KPD dialami oleh sekitar $10 \%$ wanita dalam masa kehamilannya, yang menyebabkan peningkatan risiko infeksi ibu dan infeksi pada bayi baru lahir (Hasaneroğlu, et al., 2014). Bayi yang lahir dengan keadaan warna air ketuban keruh berisiko 10 kali lipat menderita infeksi daripada bayi dengan keadaan warna air ketuban tidak keruh. Air ketuban keruh terjadi pada 10-20\% dari seluruh kelahiran. Air ketuban bukan media kultur yang baik untuk bakteri, tetapi bila ada sejumlah mekonium yang ada di dalamnya dapat meningkatkan pertumbuhan bakteri. Janin yang terpapar dengan air ketuban bercampur mekonium akan berisiko lebih tinggi terhadap infeksi daripada bayi dengan air ketuban tidak keruh (Kosim, Rini \&Suromo, 2010). Infeksi pada ibu saat proses kelahiran terutama infeksi genital adalah jalur transmisi 
Jurnal Kebidanan Mutiara Mahakam, Vol 8, No 1, 2020, Hal 1-7

maternal dan berperan penting dalam kejadian infeksi neonatal. Infeksi hematogen transplasental selama atau segera sebelum persalinan dapat terjadi walau infeksi lebih mungkin terjadi saat neonatal melewati jalan lahir (Kosim, 2009).

Tujuan dilakukannya penelitian ini untuk mengetahui gambaran ketuban pecah dini, warna ketuban jelek dan infeksi ibu dengan kejadian infeksi pada bayi baru lahir di RSUD Abdul Wahab Sjahranie Samarinda.

\section{METODE PENELITIAN}

Penelitian ini merupakan penelitian deskriptif dengan menggunakan metode cross sectional. Penelitian ini dilakukan di instalasi rekam medik RSUD Abdul Wahab Sjahranie Samarinda. Populasi dari penelitian ini adalah seluruh bayi baru lahir yang memiliki faktor risiko infeksi dari ibu yang meliputi ketuban pecah dini, warna ketuban jelek (hijau dan mekonium) dan infeksi ibu pada periode November 2017 - April 2018. Pengambilan sampel dilakukan dengan menggunakan teknik total sampling. Kriteria inklusi pada penelitian ini adalah bayi yang dilahirkan di RSUD Abdul Wahab Sjahranie Samarinda, bayi aterm dengan berat badan lahir $\geq 2.500$ gram, dan bayi yang memiliki data minimal salah satu dari faktor risiko ibu yang terdiri dari KPD atau warna ketuban jelek atau infeksi ibu dalam status rekam medis, sedangkan kriteria eksklusi untuk penelitian ini adalah bayi yang dilakukan pemasangan tindakan invasif dan bayi yang lahir dengan kelainan kongenital. Variabel bebas dalam penelitian ini adalah ketuban pecah dini, warna ketuban jelek dan infeksi ibu, sedangkan variabel terikat adalah infeksi pada bayi baru lahir.

Definisi operasional ketuban pecah dini adalah pecahnya selaput ketuban dengan pelepasan cairan ketuban lebih dari 1 jam tanpa ada tanda-tanda persalinan berdasarkan rekam medis. Warna ketuban jelek adalah warna air ketuban yang dilihat pada saat ibu bersalin meliputi warna hijau dan mekonium berdasarkan rekam medis. Infeksi ibu adalah masuknya mikroorganisme ke dalam tubuh saat wanita hamil, yang kemudian menyebabkan timbulnya tanda atau gejala penyakit berdasarkan rekam medis. Infeksi pada bayi baru lahir adalah suatu kondisi dimana bayi baru lahir mengalami penyakit yang disebabkan oleh mikroorganisme, seperti bakteri, virus, jamur atau protozoa berdasarkan rekam medis.Analisis data menggunakan uji univariat untuk mengetahui sebaran data masing-masing variabel.

\section{HASIL DAN PEMBAHASAN}

Penelitian ini dilakukan di instalasi rekam medik RSUD Abdul Wahab Sjahranie Samarinda dengan jumlah sampel sesuai dengan kriteria inklusi dan eksklusi adalah 99 sampel. 
Jurnal Kebidanan Mutiara Mahakam, Vol 8, No 1, 2020, Hal 1-7

Tabel 1. Distribusi Frekuensi Karakteristik Ibu dan Bayi di RSUD Abdul Wahab Sjahranie Samarinda

\begin{tabular}{lcc}
\hline \multicolumn{1}{c}{ Karakteristik } & N (99) & \% (100) \\
\hline Jenis Kelamin Bayi & & \\
• Laki-laki & 49 & 49,5 \\
• Perempuan & 50 & 50,5 \\
Jenis Persalinan & & \\
- Spontan & 42 & 42,4 \\
- Sectio Caesarea & 57 & 57,6 \\
Kondisi Ketuban Pecah Dini & & \\
- Ya & 18 & 18,2 \\
• Tidak & 81 & 81,8 \\
Kondisi Warna Ketuban & & \\
• Jelek & 62 & 62,6 \\
• Jernih & 37 & 37,4 \\
Kondisi Leukositosis Ibu & & \\
• Ya & 15 & 15,2 \\
• Tidak & 84 & 84,8 \\
Infeksi Bayi Baru Lahir & & \\
• Positif & 2 & 2,0 \\
• Negatif & 97 & 98,0 \\
\hline
\end{tabular}

Penelitian ini menunjukkan bayi baru lahir dari ibu yang memiliki faktor risiko infeksi lebih banyak terjadi pada perempuan dibandingkan dengan laki-laki dengan kejadian positif infeksi terjadi pada bayi dengan jenis kelamin perempuan dan laki-laki masing-masing sebanyak1 orang. Hasil ini sejalan dengan penelitian Widayati, et al. (2016) yang menunjukkan jenis kelamin bayi yang mengalami infeksi berjumlah sama. Hal ini tidak sesuai dengan teori yang menyatakan bahwa bayi dengan jenis kelamin laki-laki lebih berisiko mengalami infeksi neonatorum lebih besar daripada perempuan karena aktivitas bayi laki-laki lebih tinggi daripada perempuan sehingga memerlukan oksigen lebih banyak dan bila kandungan oksigen dalam tubuh berkurang akan menyebabkan bakteri anaerob mudah berkembang (Simbolon, 2008).

Hasil penelitian ini juga menunjukkan bahwa bayi baru lahir yang memiliki faktor risiko infeksi dilahirkan dengan jenis persalinan sectio caesarea lebih banyak dibandingkan dengan jenis persalinan spontan. Hasil ini sesuai dengan penelitian Roeslani, et al. (2013) di Rumah Sakit Ciptomangunkusumo dimana pada penelitian tersebut jenis persalinan yang paling banyak adalah dengan sectio caesarea. Serupa dengan Rumah Sakit Ciptomangunkusumo, RSUD Abdul Wahab Sjahranie sebagai tempat penelitian ini adalah fasilitas kesehatan tersier dimana merupakan rumah sakit rujukan sehingga kebanyakan ibu hamil yang datang memiliki risiko tinggi dalam persalinan sehingga diharuskan untuk melakukan sectio caesarea. 
Jurnal Kebidanan Mutiara Mahakam, Vol 8, No 1, 2020, Hal 1-7

Pada penelitian ini didapatkan bahwa ibu yang tidak mengalami KPD lebih banyak daripada ibu yang mengalami KPD. Hal ini tidak jauh berbeda dengan penelitian yang dilakukan Meliya dan Priscilla (2013) di RSUP Dr. M. Djamil Padang yang mendapatkan ibu dengan KPD dengan persentase yang lebih sedikit daripada ibu yang mengalami KPD. Namun hasil ini tidak sejalan dengan penelitian yang dilakukan Sari dan Mardalena (2016) dimana penelitian tersebut menunjukkan persentase kejadian ibu dengan KPD banyak daripada yang tidak mengalami KPD.

Pada penelitian ini ditemukan ibu dengan warna ketuban terbanyak yaitu warna ketuban jelek yang terdiri dari hijau dan mekonium daripada ibu dengan warna ketuban jernih. Penelitian ini sejalan dengan penelitian Palupi, Widada dan Fitrianingsih (2019) yang menunjukkan ibu dengan cairan ketuban bercampur mekonium lebih banyak daripada ibu dengan cairan ketuban jernih. Menurut teori, mekonium dapat keluar dalam berbagai kondisi klinis, salah satunya ialah pada sebagian besar janin, pasase mekonium dicegah oleh kontraksi tonik sfingter ani dan oleh kurangnya peristaltic usus. Dengan demikian, pada janin kurang bulan dengan mekanisme gastrointestinal yang imatur, jarang terjadi kebocoran mekonium. Sebaliknya, untuk janin pasca matur, traktus intestinal matur, pasase mekonium mungkin normal terjadi, dan pewarnaan ketuban didapatkan sekitar 30\% dari kelahiran ini (Walsh \& Fanaroff, 2007).

Berdasarkan hasil penelitian, ditemukan ibu dengan keadaan tidak leukositosis lebih banyak sebesar $84,8 \%$ dibandingkan ibu dengan leukositosis. Dalam penelitian ini, yang dijadikan sebagai sampel pada variabel leukositosis ibu adalah kelompok ibu dengan leukositosis yang telah mendapatkan antibiotik intrapartum. Hasil penelitian ini sejalan dengan penelitian Adriani, et al. (2018) dimana hasil penelitian menunjukkan bahwa ibu dengan leukositosis lebih sedikit daripada ibu yang tidak mengalami leukositosis.

Hasil pada penelitian ini menunjukkan bahwa bayi baru lahir dengan infeksi sebanyak 2 orang dan bayi baru lahir yang tidak infeksi sebanyak 97 orang. Dari 2 kasus bayi baru lahir yang positif infeksi, masing-masing berasal dari ibu dengan faktor risiko KPD dan warna ketuban jelek serta ibu dengan keadaan leukositosis. Hasil penelitian ini sejalan dengan penelitian Christopeher dan Rose (2016) dimana dari 5 bayi yang diduga infeksi, faktor risiko yang berperan ialah KPD dan pemeriksaan vagina sebanyak 3 kali setelah KPD serta perubahan pada cairan ketuban. Dari penelitian tersebut juga didapatkan hasil hanya 2 bayi yang dinyatakan infeksi melalui kultur darah dengan faktor risiko demam intrapartum ibu, KPD dan pemeriksaan vagina sebanyak lebih dari 3 kali setelah pecahnya ketuban. Rendahnya angka kejadian infeksi ini dapat disebabkan karena keadaan bayi yang lahir cukup bulan dan memiliki berat badan normal sehingga dapat diasumsikan bahwa keadaan bayi yang baik memiliki imunitas yang baik pula, dan juga tidak semua bayi menunjukkan gejala khas sehingga menyebabkan sulitnya penegakan 
Jurnal Kebidanan Mutiara Mahakam, Vol 8, No 1, 2020, Hal 1-7

diagnosis infeksi pada bayi baru lahir. Higiene yang baik dan pemberian antibiotik profilaksis intrapartum pada ibu juga mengurangi angka kejadian infeksi pada bayi baru lahir.

\section{SIMPULAN}

1. Jenis kelamin bayi baru lahir yang dilahirkan dari ibu yang memiliki faktor risiko untuk menularkan infeksi kepada anaknya lebih banyak perempuan dibandingkan laki-laki dengan kejadian positif infeksi bayi baru lahir masing-masing berjenis kelamin perempuan dan laki-laki.

2. Jenis persalinan yang paling banyak dijalani oleh ibu yang memiliki faktor risiko untuk menularkan infeksi kepada anaknya adalah section caesarea.

3. Bayi yang memiliki faktor risiko infeksi lebih banyak berasal dari ibu yang tidak mengalami KPD dibandingkan ibu yang mengalami KPD.

4. Bayi yang memiliki faktor risiko infeksi lebih banyak berasal dari ibu dengan keadaan air ketuban jelek dibandingkan dari ibu dengan keadaan air ketuban jernih.

5. Bayi yang memiliki faktor risiko infeksi lebih banyak berasal dari ibu dengan keadaan tidak leukositosis dibandingkan dari ibu dengan keadaan leukositosis.

6. Bayi yang didiagnosis positif infeksi lebih sedikit dibandingkan dengan bayi yang tidak terinfeksi, dengan kejadian positif infeksi bayi baru lahir masing-masing berasal dari ibu dengan KPD dan warna ketuban jelek serta ibu dengan keadaan leukositosis.

\section{DAFTAR PUSTAKA}

Adriani, R., Yantri, E., \& Mariko, R. (2018). Peran Sistem Skoring Hematologi dalam Diagnosis Awal Sepsis Neonatorum Awitan Dini. Sari Pediatri.

Boskabadi, H., Maamouri, G., Akhondian, J., Zakerihamidi, M., Seyed, J., Ghazvini, K., et al (2016). Neonatal infections: a 5-Year Analysis in Neonatal Care Unit in North East of Iran. Int J Pediatr.

Christopher, U., \& Rose, C. A. (2016). Is there any association between maternal risk factors and early neonatal sepsis?. International Journal of Biomedical Research.

Hasaneroğlu, Bakacak, M., Sühhabostanc1, M., Eminesedagüvendağgüven, Attar, R., Özgekızılkale, et al. (2014). Relationship between Premature Rupture of Membranes and Collagen Amount in Chorioamnionitic Membranes in Term Pregnancy. Global Journal of Medical Research: E Gynecology and Obstetrics .

Kementrian Kesehatan Republik Indonesia. (2018). Profil Kesehatan Indonesia Tahun 2017. Kementrian Kesehatan RI.

Kosim, M. S. (2009). Infeksi Neonatal Akibat Air Ketuban Keruh. Sari Pediatri .

Kosim, M. S., Rini, A. E., \& Suromo, L. B. (2010). Faktor Risiko Air Ketuban Keruh Terhadap Kejadian Sepsis Awitan Dini pada Bayi Baru Lahir. Sari Pediatri . 
Jurnal Kebidanan Mutiara Mahakam, Vol 8, No 1, 2020, Hal 1-7

Meliya, I., \& Priscilla, V. (2013). Gambaran Kejadian Infeksi Bayi Baru Lahir di Bagian Perinatologi RSUP Dr. M. Djamil Padang Tahun 2012. NERS JURNAL KEPERAWATAN .

National Institute for Health and Care Excellence. (2014). Neonatal Infection. NICE .

Ocviyanti, D., \& Wahono, W. T. (2018). Risk Factors for Neonatal Sepsis in Pregnant Women with Premature Rupture of the Membrane. Hindawi Journal of Pregnancy .

Palupi, J., Widada, W., \& Fitrianingsih, A. A. (2019). Risiko Asfiksia Neonatorum Berdasarkan Keadaan Air Ketuban di RSU Dr. H. Koesnadi Bondowoso Tahun 2018. The Indonesian Journal of Health Science.

Roeslani, R. D., Amir, I., Nasrulloh, M. H., \& Suryani. (2013). Penelitian Awal: Faktor Risiko pada Sepsis Neonatorum Awitan Dini. Sari Pediatri .

Sankar, M., Neogi, S., Chauhan, M., Srivastava, R., Prabhakar, P., Khera, A., et al. (2016). State of newborn in India. Journal of Perinatology, 56.

Sari, E., \& Mardalena. (2016). Faktor-faktor yang Berhubungan dengan Kejadian Sepsis pada Neonatorum di Rumah Sakit Moehammad Hoesin Palembang. RAKERNAS AIPKEMA .

Simbolon, D. (2008). Faktor Risiko Sepsis Pada Bayi Baru Lahir di RSUD Curup Kabupaten Rejang Lebon. Jurnal Kesehatan .

Stefanovic, I. M. (2011). Neonatal Sepsis. Biochemia medica .

United Nations Children's Fund. (2018). Neonatal Mortality. Retrieved 2019, from https://data.unicef.org/topic/child-survival/neonatal-mortality/

Walsh, M., \& Fanaroff, J. (2007). Meconium stained fluid: approach to the mother and the baby. Clin Perinatol .

Widayati, K., Kurniati, D. P., \& Windiani, G. A. (2016). Faktor Risiko Sepsis Neonatorum di Ruang Perinatologi Rumah Sakit Umum Pusat Sanglah Denpasar. Public Health and Preventive Medicine Archive . 